\title{
Identifying categories of service innovation: A review and synthesis of the literature
}

\author{
Hannah Snyder, Lars Witell, Anders Gustafsson, Paul Fombelle and Per Kristensson \\ Journal Article
}

\section{Tweet}

N.B.: When citing this work, cite the original article.

Original Publication:

Hannah Snyder, Lars Witell, Anders Gustafsson, Paul Fombelle and Per Kristensson, Identifying categories of service innovation: A review and synthesis of the literature, Journal of Business Research, 2016. 69(7), pp.2401-2408.

http://dx.doi.org/10.1016/j.jbusres.2016.01.009

Copyright: Elsevier

http://www.elsevier.com/

Postprint available at: Linköping University Electronic Press

http://urn.kb.se/resolve?urn=urn:nbn:se:liu:diva-125724

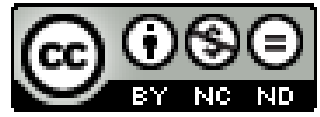

I.U UNNGDESGS 
Identifying categories of service innovation: A review and synthesis of the literature

\author{
Hannah Snyder, Linköping University \\ Lars Witell, Linköping University and Karlstad University \\ Anders Gustafsson, Karlstad University and Norwegian Business School \\ Paul Fombelle, Northeastern University \\ Per Kristensson, Karlstad University
}

Submission: October 2014

Revision: May 2015

Second revision: November 2015

Send correspondence to Lars Witell (Corresponding author), Service Research Center, Karlstad University and Business Administration, Linköping University, Sweden.

Telephone: +46736209516; E-mail: lars.witell@liu.se; Hannah Snyder, Quality Technology and Management and HELIX Vinn Excellence Centre, Linköping UniversityE-mail: hannah.snyder@liu.se; Anders Gustafsson, Service Research Center, Karlstad University and Norwegian Business School, E-mail: anders.gustafsson@kau.se; Paul Fombelle, D’Amore-McKim School of Business, Northeastern University, E-mail: p.fombelle@neu.edu; Per Kristensson, Service Research Center, Karlstad University. Email: per.kristensson@kau.se. 


\begin{abstract}
Service innovation acts as society's engine of renewal and provides the necessary catalyst for the service sector’s economic growth. Despite service innovation’s importance, the concept remains fuzzy and poorly defined. Building on an extensive and systematic review of 1,046 academic articles, this research investigates and explores how service innovation is defined and used in research. Results identify four unique service innovation categorizations emphasizing the following traits: (1) degree of change, (2) type of change, (3) newness, and (4) means of provision. The results show that most research focuses inward and views service innovation as something (only) new to the firm. Interestingly, service innovation categorizations appear to neglect both customer value and financial performance.
\end{abstract}

Keywords: Service innovation, categorization, radical, incremental, process, value cocreation, literature review 


\section{Introduction}

In today’s business landscape, service firms must continuously renew their processes and offerings to remain competitive (Thakur \& Hale, 2013). Service innovation operates as the engine of economic growth and pervades all service sectors. Spurred by an innovation focus, service firms have grown tremendously over the past decade. Examples of service innovation growth include Internet services (e.g., Twitter and Netflix), industrial giants (e.g., IBM and GE) who have re-vitalized their competitive positions by focusing on customer service, and restaurants (e.g., Chipotle and Starbucks) and other retailers (IKEA and Amazon) who re-define their businesses by creating new customer experiences. Tremendous service innovation growth also occurs in the social services sector, or innovations targeting the under-privileged, (e.g., Mulgan, Tucker, Ali, \& Sanders, 2007), and the public sector (e.g., Windrum \& Koch, 2008). Despite the considerable attention given to studying service innovation, research still struggles to answer the most basic question: What is service innovation?

Commonly, categorizations addressing degree of change (e.g., radical versus incremental) describe service innovation. However, this approach does not identify what part of the offering qualifies as the service innovation. One traditional view of innovation builds on technological breakthroughs (Schumpeter, 1934; van der Aa \& Elfring, 2002). Inferring service innovation only as a technology breakthrough limits the scope and impact of the concept and hinders theoretical development. Arguably, service innovation encompasses a much broader perspective. Ostrom et al. (2010) suggest that service innovation creates value for customers, employees, business owners, alliance partners, and communities through new and/or improved service offerings, service processes, and service business models. Consequently, adding service to innovation introduces new or alternate perspectives. The question is whether new perspectives on service innovation truly provide a 
better explanation for the growth in services and why a new service succeeds or fails (Witell et al., 2015).

Traditional service innovation categorizations separate radical and incremental innovations (see Gallouj \& Weinstein, 1997) and product and process innovations (Vaux, Halliday, \& Trott, 2010). Ostrom et al. (2015) recommend identifying how various categories of service innovations interrelate (e.g., service-product to service-process). More recent categorizations propose that service innovation differs from traditional innovation perspectives in aspects such as the customer's changing role (Michel, Brown, \& Gallan, 2008), Internet use (Dotzel, Shankar, \& Berry, 2013), and new business models (Hsieh, Chiu, Wei, Yen, \& Cheng, 2013). Gallouj and Savona (2008) argue that a materiality bias exists in innovation research - ignoring the immaterial aspects - leading to inaccurate measurements of the service industry's economic impact and performance. The evidence suggests that ignoring a service innovation's uniqueness leads to underestimating the innovation's impact in the service sector. Further, Gallouj and Savona (2008) question the existing categorizations and suggest a need for new categorizations to better understand the nature of service innovation.

The present study investigates service innovation's meaning through an extensive literature review and synthesis of the concept's various categorizations. A review of 1,046 research articles identifies and defines the various service innovation categories and provides a platform to analyze how these categories help to understand the overall concept. Investigating service innovation categories identifies themes, explores how they differ, and explains how the different themes comprise a whole (MacInnis, 2011). This study contributes to the service innovation literature in two ways. First, analyzing categories provides a different perspective on service innovation. Previous literature reviews primarily employ assimilation, demarcation, and synthesis perspectives to summarize service 
innovation research (e.g., Carlborg, Kindström, \& Kowalkowski, 2014; Coombs \& Miles, 2000; Ordanini \& Parasuraman, 2010; Droege, Hildebrand \& Forcada, 2009). An alternative perspective provides new insights and a greater understanding. Second, this study clarifies "what" a service innovation is - an innovation process output - that contrasts with other literature reviews that concentrate on both the "what" and the "how" of service innovation (e.g., Carlborg et al., 2014; Ordanini \& Parasuraman, 2010). Focusing on the "what” of service innovation helps provide an in-depth analysis of the service innovation concept and distinguishes service innovation from related concepts, such as new service development. From 43 service innovation categorizations, four unique themes emerge: (1) degree of change, (2) type of change, (3) newness, and (4) means of provision. Arguably, most service innovation categorizations focus inward and view service innovation as something internally new to the firm. Crucially, the literature poorly addressed how service innovations affect customer value and financial performance.

\section{Service innovation}

\subsection{Defining service innovation}

Schumpeter (1934) argues that economic development is driven by innovation. He makes an important distinction between invention and innovation and argues that inventions have no inherent value. Instead, Schumpeter defines innovation as a separate activity through which inventions are carried out in the market for a commercial purpose. Thus, for an invention must be introduced in the market and generate a substantial profit in order to become an innovation. Schumpeter argues the process of developing a new offering must be distinguished from the outcome or the commercialization. Schumpeter (1934 p. 66) defines innovations as the "carrying out of new combinations.” Building on his work, researchers develop the Schumpeterian view of service innovation (see Gallouj \& Savona, 2008;Windrum \& García-Goñi, 2008). This view emphasizes recombinative innovations as 
central to service innovation and suggests that they frequently appear in new firms (Gallouj \& Weinstein, 1997). According to Toivonen and Tuominen (2009), a Schumpeterian view of service innovation assumes that innovation: (1) is carried into practice, (2) provides benefits to the developer, and (3) is reproducible. Interestingly, Schumpeter (1934) considers customer needs as given. Developers first initiate economic change and then educate users about the new offering's benefits. Implicitly, this development pattern represents an inside-out perspective. Building on a Schumpeterian perspective, Toivonen and Tuominen (2009 p. 893) suggest "service innovation is a new service or such a renewal of an existing service which is put into practice and which provides benefit to the organization that has developed it; the benefit usually derives from the added value that the renewal provides the customers." Following this reasoning, an innovation must be new to both the developer and a broader set of actors. The Schumpeterian view of service innovation emphasizes the central role of financial returns (Drejer, 2004) but does not account for customer value.

Prior studies use different methods to explain and define service innovation. Whereas some studies used an overall definition to state the meaning of service innovation, other studies include dimensions or categories to define the concept (Gallouj \& Weinstein, 1997). An overall definition explains service innovation by describing the innovation's core characteristics (e.g., Ostrom et al., 2010). For example, the Organisation for Economic Cooperation and Development (OECD) (2005) defines service innovation as launching a new or significantly improved product (good or service) or process, a new marketing method, or a new organizational method in business practices, workplace organization, or external relations. Menor and Roth (2007) suggest that service innovation - either an addition to current services or a change in the delivery process - is an offering not previously available to customers that requires changes in the competences applied by service providers and 
customers (Ordanini \& Parasuraman, 2011). Frequently, the overall definitions are rather general and suggest some core characteristics are insufficient for identifying service innovation in practice.

Alternatively, a service innovation may involve changes in several dimensions of an existing service. This view follows the Lancasterian view in which a service is based on the provider's characteristics, client competencies, technical characteristics, and final users' service characteristics (Gallouj \& Weinstein, 1997; Saviotti \& Metcalfe, 1984). This multidimensional view is more prominent in recent research (see Päällysaho \& Kuusisto, 2008; Zolfagharian \& Paswan, 2008). Using changes in dimensions to define service innovation frequently depends on multiple changes to an existing offering. The plethora of dimensions suggests that service innovation is becoming a broader concept and firms can innovate more than prior research suggests.

\subsection{Categories of service innovation}

Another way to understand service innovation is through categories or classifications that distinguish by innovation type. Each category contains a number of objects that are considered equivalent; therefore, categorization becomes a system comparing how different categories relate to each other (Rosch, Mervis, Gray, Johnson, \& Boyes-Braem, 1976). Schumpeter (1934) proposes several different innovation forms: introduction of a new good, introduction of a new production means, and the discovery of a new source of raw materials, new markets, or new organizations. Taking a Schumpeterian view of service innovation, Drejer (2004) emphasizes the dichotomy between product and process as two main service innovation categories. In addition, the radical and incremental innovation dichotomy is a common service innovation categorization that suggests bifurcating innovations based on the degree of change. To use a dichotomy to separate mutually exclusive types of innovation is common. Several benefits exist from developing and using categorizations because they 
create useful heuristics and provide a systematic basis for comparison and operationalization (Smith, 2002). Lovelock (1983) emphasizes the practical relevance of categorizations in marketing and suggests that distinctions can benefit different types of marketing strategies and management tools. Different marketing and innovation strategies might be relevant for different service innovation categories (Hsieh et al., 2013). However, using different categories in research can be troublesome because operationalizing them might be difficult. Hsieh et al. (2013) argue that most studies using service innovation categorizations do not provide specific examples of the different category types despite the importance of such details. Frequently, categories are neither exhaustive nor mutually exclusive and they are typically based on arbitrary or ad hoc criteria (Smith, 2002). Arguably, discerning these alternative categorizations is essential to gaining a deeper understanding service innovation. The following sections investigate the various service innovation categorizations through a comprehensive literature review.

\section{Method}

A systematic review methodology identified research that focuses on service innovation (Tranfield, Denyer, \& Smart, 2003), a process that includes several steps. First, the research questions were stated and guidelines developed for collecting the literature. Next, a plan for classifying, describing, and coding the literature was developed. As a final step, the literature was synthesized.

Because this research focuses on reviewing and synthesizing different conceptualizations of service innovation categories, the primary search strategy is to identify conceptual or empirical research articles that include categories of service innovation. To capture this concept, inclusion and exclusion criteria were developed. To be eligible for first inclusion in the sample, a broad set of criteria was used to ensure that all relevant research 
articles are captured: (1) main focus on service innovation, (2) peer-reviewed empirical or conceptual papers, (3) published in English, and (4) full text access (see Figure 1).

A search was conducted for research articles that include the terms "service/s innovation" or "innovation in service/s" in their abstract, title, or keywords. These search terms were selected to cover as many relevant research articles as possible. To obtain a full overview of the research field, care was to taken to prevent limiting the scope of the research to any particular field, subject, or specific journal. Managerial books and reports were excluded. To remain focused, some concepts that might appear related to service innovation are not included in this review. To be consistent with Schumpeter (1934), new service development (NSD) - sometimes used interchangeably with service innovation - was omitted (Menor \& Roth, 2002). Previous reviews of service innovation such as Droege et al. (2009) and Carlborg et al. (2014) do not make this separation and (i.e., they use a classification based on output to classify processes). This study's focus is on service innovation as an output, whereas the literature on NSD focuses on the development of service innovation.

The literature search was carried out during the spring of 2014, and the initial search identified 1,046 articles, of which 956 were in English and 879 existed in full text. All 879 articles were read in full. Although many articles used the term service innovation in the abstract, few defined, conceptualized, or emphasized the concept. Guided by MacInnis’s (2011) framework for conceptual contributions in marketing, a subset of 225 articles was selected for further analysis. This literature review style builds on the differentiation between the conceptualizations of service innovation categories. Drawing on Rosch et al. (1976 p. 383), a category is defined as "a number of objects that are considered equivalent.” A categorization then becomes a system by which different categories relate to other categories. The research both provides a typological framework of service innovation and 
identifies similarities and differences in the categorizations. Two authors independently read these articles and identified 43 that provided a conceptualization of service innovation using categories (such as radical and incremental). An analysis followed MacInnis’s (2011) process of conceptual thinking - the process of understanding a situation or problem by identifying patterns and key underlying properties. Two authors sorted the identified articles into different categorizations that focus on the main categories. This process continued until the two authors sorted and agreed on the identified categorizations. To be eligible for categorization, a category must have been used in more than one paper. Finally, four alternative category conceptualizations were identified and subsequently investigated.

No agreement exists on a single concept to describe service innovation in the service sector. Instead, the literature uses several concepts. The most common concepts are service innovation ( $\mathrm{n}=21)$ and innovation $(\mathrm{n}=14)$. Other concepts, such as health service innovation, services innovation, and experience service innovation appear only in one paper. Because these concepts are similar in their operationalization of service innovation, they were categorized as different facets of service innovation.

Figure 1 here

\section{Results}

\subsection{Different service innovation categories}

A systematic literature review identified four different categorizations that describe service innovation. These different categories are degree of change, type of change, newness, and means of provision.

The most common service innovation category addresses the degree of change $(\mathrm{n}=17)$. This category includes the classical distinction between radical and incremental innovation extensively used in research. The second most common category is the type of change ( $\mathrm{n}=12)$. This area includes discussion distinguishing between product and process 
innovation. The third service innovation category examines the service’s newness $(n=4)$, addressing the offering's perceived novelty to the innovating firm or the receiving customers. The fourth category covers means of provision $(n=4)$ and addresses how organizations innovatively restructure to provide a new service. Additionally, six articles use categorizations not fitting into any of the other categories. Typically, areas are sectorspecific or discuss issues only addressed only in one paper. The following sections discuss the four main service innovation categorizations in greater detail.

\subsection{Degree of change (radical versus incremental)}

The offering's degree of change is the most common basis for categorizing service innovations. Degree of change includes the distinction between radical and incremental service innovation (see Table 1). Oke (2007) views service innovation as new developments in activities undertaken to deliver core services and differentiates between radical and incremental innovation by investigating offering revisions, line extensions, and new markets. Janeirio, Proença, and Gonçalves (2013) explain radical and incremental service innovations differ due to substantial differences in technology (both current and new) and whether or not consumer needs (existing or new) is met. In contrast, Brown and Osborne (2013) suggest that a transformational (radical) service innovation is a distinctive category of discontinuous change. This change includes a new service, a new policy, a transformed process, or a new configuration of an existing set of relationships to fulfill a task. Thus, Janeirio et al. (2013) and Brown and Osborne (2013) conceptualize radical service innovation quite differently.

The distinction between radical and incremental innovation often identifies the practices that a service firm should adopt to succeed when developing new offerings. For example, a new service's degree of radical change affects the level of customer involvement (see Gustafsson, Kristensson, \& Witell, 2013). The literature is consistent on how the effect 
of a specific practice or method differs between radical and incremental innovation.

However, a gap remains due to limited knowledge about how firms should organize their new service development to succeed with both radical and incremental service innovation.

Gallouj and Weinstein (1997) explain that radical innovation involves creating a completely new offering. The difference between radical and incremental service innovation depends on the degree that new service characteristics differ from the previous offering. Therefore, a radical innovation shares no common elements with the previous offering. A common consequence is that customers must learn new competences to be able to co-create value through the offering. Following Gallouj and Weinstein (1997), both improvement and incremental innovation suggest limited changes to service characteristics. Incremental innovation adds new elements to the offering without changing the overall offering, whereas improvement innovation improves certain characteristics without any change in the overall offering. Such developments frequently involve interactions with customers and associate with either new or existing services (Oke, 2007).

Recombinative service innovation is another important area and arguably the most common service innovation form (Gallouj \& Weinstein, 1997). Recombinative innovations are service characteristic changes that either combine one or more service characteristics or separate the characteristics of a pre-existing service (Gallouj \& Savona, 2008). A mobile phone service study demonstrates how companies provide increasing recombinative innovations as the market grows (Corrocher \& Zirulia, 2010). This study suggests that recombinative innovation involves less uncertainty than introducing an offering with new characteristics. However, following a recombinative innovation mode, the output can be either incremental or radical.

Table 1 here 


\subsection{Type of change (product versus process)}

The second most common service innovation categorization distinguishes between innovation in products and processes (see Table 2). A survey of 5,574 firms distinguishes between innovation in product/service, process, organization, and marketing (Grolleau, Mzoughi, \& Pekovic, 2013). On average, most firms innovate using one of these four categories. The Oslo Manual (OECD, 2005) employs this categorization method (product, process, organizational, and marketing innovation) providing policy recommendations to support innovation efforts within the European Union. Further, Amara, Landry, and Doloreux (2009) suggest that service innovation is more multidimensional than innovation in manufacturing industries. This work conceptualizes service innovation into six categories: product, process, delivery, strategic, managerial, and marketing. Amara et al. (2009) further suggest that the other four categories (excluding product and process) represent nontechnological forms of innovation that largely overlap with organizational innovation. The traditional product versus process distinction suggests that the former relates to new product introduction or significantly improved products, whereas the latter relates to a new or significantly improved production processes (Amara et al., 2009).

Further, service innovation divides into interactive and supportive service innovations. Interactive service innovations are external (service concept), whereas supportive service innovations are internal (service production) (Salunke, Weerawardena, \& McColl-Kennedy, 2013). This conceptualization focuses on value co-creation and customer experience. Interactive service innovations potentially create sustainable competitive advantages, whereas supportive service innovations offer no such direct effect. Innovative changes that the customer discerns and experiences (interactive service innovations) provide avenues for implementing a superior value-creating strategy difficult for competitors to duplicate (Salunke et al., 2013). 


\section{Table 2 here.}

\subsection{Newness (new to the market versus new to the firm)}

The third service innovation conceptualization requires the service to be "new” for either the firm or the customer (see Table 3). However, understanding newness is rather ambiguous. Product innovation research views newness as the difference between a new and an existing offering (Zirger \& Maidique, 1990). New market offerings refer to service innovations that require training or extra effort by customers for product adoption. This category suggests the innovation's success depends on changes in customer behavior (i.e., viewed from a market point of view). Chen, Tsou, and Huang (2009) identify two service innovation types with different degrees of newness: new service channels for existing services (delivering the same service in a new way), and new service channels for new services (delivering new service in a new way). Others view service innovation as service offerings and processes that are new to the firm or to the market (customer) (e.g., Mansury \& Love, 2008; Thakur \& Hale, 2013). Differentiating newness from the firm’s or the market's perspective is a core distinction constituting a service innovation. Traditionally, market newness is central to an innovation; however, the business press and policymakers are changing the focus to being new to the firm (Toivonen \& Tuominen, 2009). Toivonen and Tuominen (2009) argue that "newness" is a relative concept, and "new to a firm" suggests that a service firm adopting or copying existing services becomes an innovator.

\section{Table 3 here.}

\subsection{Means of provision (technology versus organization)}

The fourth conceptualization considers the resources used to operationalize the service innovation as the key point of departure. Viewing service innovation as a change within the organization often is one service innovation category. However, several research articles view the organization as the central mechanism for service innovation (see Table 4). Dotzel 
et al. (2013) introduces e-innovations and p-innovations to emphasize the key role that the Internet and human interaction plays in service innovation. E-innovations are new services that provide customer benefits primarily through the Internet, whereas p-innovations are new services delivered primarily through human interactions. Given e-innovation's scalability, managers focus their attention on e-innovations rather than p-innovations. The focus on e- and p-innovations resembles the discussion in service research regarding hightouch versus high-tech services. He and Abdous (2013) further divide innovations into service, technological, and administrative innovations.

Yoon, Kim, and Rhee (2012) do not distinguish between technology and the organization; however, they identify three service innovation types: (1) new or improved service products, (2) new or improved ways to design and produce services, and (3) organizational innovation and management of the innovation process. This conceptualization provides alternative ways to realize organizational innovation, suggesting that innovation can occur in the production process, the development process, and the actual “organizing” of the firm.

\section{Table 4 here.}

\subsection{Other categorizations}

In addition to the four categorization types previously described, six articles identify service innovation in ways that do not fit into any of the aforementioned categorizations. Frequently, these categorizations are sector specific or use categories addressed only in one paper. As an example, Bröchner (2010) describes material, informational, methodological, and contractual service innovations in the construction industry. These categorizations seem meaningful for the specific industry, but they are not generalizable to other sectors. Gebauer, Krempl, Fleisch, and Friedli (2008) distinguish between separated and integrated productrelated service innovations that depend on the relationship between the service and the 
product component. This method also has merit; however, the distinction seems to apply best in industrial settings and when services are bundled with a manufactured good.

\section{Discussion: Altering the view from internal to external value}

The results reveal four themes for service innovation categorizations: degree of change, type of change, newness, and means of provision (see Table 5). These categorizations emphasize different service innovation traits and explain why researchers come to different conclusions about whether or not innovation occurs in service firms. Prior research primarily categorizes either product versus process innovations or radical versus incremental innovations (Gallouj \& Weinstein, 1997). Current research adds new categorizations that are either sector specific or that emphasizes specific traits but do not integrate or are not positioned against existing categorizations, and they fail to show their superiority. The following section discusses the present use of categories to understand service innovation and how using these categories assist in developing the research field.

\subsection{Does innovation occur in service firms?}

Research debates whether or not innovation actually occurs in service firms (Sundbo, 1997). Many conceptualizations of radical service innovation concern a major change in service characteristics (see Gallouj \& Weinstein, 1997) that frequently emphasizes an internal perspective (e.g., resources operationalize the service). In contrast, a paucity of research suggests that radical service innovation stands out through the newness of services and/or the newness of markets (Harris, McAdam, McCausland, \& Reid, 2013). These claims suggest that service innovation should be new from an external perspective and earn a profit after being introduced in the market. This consequence highlights important questions seemingly remain neglected in service innovation research. What is newness? What is the customer's role? What is the role of financial returns? 
What is newness? This research concludes that newness is frequently viewed from the firm’s perspective (e.g., Mansury \& Love, 2008; Thakur \& Hale, 2013). Therefore, services new to the firm that exists among competitors or in different markets still are viewed as service innovations. Geographical or sector perspectives should determine an innovation's degree of newness or radicalness (Toivonen \& Tuominen, 2009). Further, a truly radical innovation typically means “new to the world,” whereas incremental innovations probably are "new to a region or a nation" or "new to a sector." The emphasis on "new to the firm" in service research strengthens the claim that service innovation frequently occurs through cumulative small changes in the offering. Giving a real meaning to the concept of newness is important to position newness as a theme in the theoretical development of the service innovation concept.

What is the customer's role? From a Schumpeterian perspective, customer needs are a given or an unproblematic base for service innovation (Schumpeter, 1934). This statement contradicts recent developments in the service-dominant logic that stress the importance of value (Vargo, Lusch, Akaka, \& He, 2010). Using an internal perspective on service innovation, one risk is that the customer does not view a service based on technology advancement as new. Therefore, newness might be best viewed from the customer's point of view. Only the customer can evaluate the value of an offering. As Vargo and Lusch (2004) conclude, value comes from usage and cannot be embedded into the production of a new good or service. Michel et al. (2008) confirm this notion by suggesting that customer roles buyer, payer, or user - must change for new services to be viewed as innovations.

What is the role of financial returns? Service innovation research lacks a focus on the new service’s market success. In addition scant attention is paid to customers' experiences of value. A firm's return on investment (financially) often is neglected. Surprisingly, in this study's sample, service innovation is not discussed in terms of market 
success. The frequent neglect of service innovation's value-creational effect on the beneficiary is peculiar. A Schumpeterian view of financial returns is disregarded; instead, the discourse focuses on the newness of the service characteristic (e.g., Gallouj \& Weinstein, 1997). For both the customer and the firm, the research appears to focus more on the innovation's characteristics rather than the value that the innovation is designed to create. Neglecting value may occur because studying or receiving unbiased information on this issue is challenging and difficult. An innovation's financial value is not completely forgotten because the literature typically uses business model innovation as a service innovation category (e.g., Hsieh et al., 2013). The emerging conceptualization of business model innovation and the ability to create a new market (e.g., Hsieh et al., 2013) serves as a proxy for market success or financial value. Plausibly, the limited discussion on the market success of service innovation indicates that such success is the result of social innovation, and innovations relate to the Internet and mobile services. Frequently, such e-innovations (Dotzel et al., 2013) increase the efficiency of service provisions or they are provided for free to improve the experience. In such service sectors, market success and financial value require alternative measures, such as the coefficient of a viral loop or the speed of market growth. Measuring the results of service innovation is a step toward showing the importance for firms, industries, and society in general.

\subsection{Failure to distinguish product and process in service innovation}

Gallouj and Savona (2008) argue that the difference between product and process presents a certain degree of ambiguity for service innovation attributable to intangibility and co-production characteristics. The product lacks physical output, but the innovation frequently is a process, a sequence of operations, or a solution to a problem. Further, separating what a product is from the service innovation process becomes difficult; arguably the distinction has no meaning (Gallouj \& Savona, 2008). Hsieh et al. (2013) support this 
view by reporting a significant difference in the ratio between product and process innovations (550 to 27), suggesting a separation problem between product and process. This distinction likely still exists in service innovation research attributable to the separation between "how” and “what” in basic service marketing models (Grönroos, 2011). Frequently, surveys include this distinction to investigate innovation in a region or country. The product and process distinction provides an opportunity to compare manufacturing and service sector innovations. Using the same categories for all parts of the economy is convenient for policymakers; however, inconsistent study results suggest that the distinction is difficult to operationalize and not suited for service innovation research.

\subsection{Using categories to understand service innovation}

The different categorizations provide diverse perspectives on service innovation (see Table 5). Degree of change and newness emphasize changes in the offering without specifying which resources change. The focus is on the outcome of the change and the two categorizations highly correlate. In other words, a radical service innovation frequently indicates new to the market, whereas an incremental service innovation frequently indicates new to the firm. Moving forward, one might argue that the true meaning of a radical service innovation should be new to the world; however, this meaning has yet to be seen in service research.

The remaining two categorizations (type of change and means of provision) view service innovation through specific types of resource changes. These two categorizations are not correlated, suggesting that a process change can be achieved through either organization or technology. Although several researchers use more than two categories (e.g., Alam, 2012; Khan \& Khan, 2009), the strength in using categories is simplicity. The frequent use of the simple distinction between radical versus incremental innovation and product versus process innovation support this notion. The main concept relating to categories is to create a 
language that is easily understood and communicated (e.g., Rosch et al., 1976). These categorizations are widely used and applicable to a broad range of offerings, including both goods and services. Therefore, the categorizations are likely independent of the perspective chosen (i.e., assimilation, demarcation, or synthesis).

\section{Conclusions}

The present research suggests that service innovation has become an imprecise and dispersed theoretical concept but remains important for explaining the service sector's growth. This paper identifies four categorizations of service innovation and shows the benefits and drawbacks of each one. The service innovation categorizations depart from changes in either the offering or the resources and depend on the degree of change, type of change, newness and means of provision. In particular, the different categories are radical versus incremental, product versus process, new to the firm versus new to the market, and technology - organization. The literature reports extensive use of the product-process distinction (Gallouj \& Savona, 2008); however, the difficulties in separating product from process in service research limit this dimension's usefulness.

One main study implication is the proposition that a service innovation should be viewed as changes in value. The Schumpeterian view of service innovation emphasizes value (Schumpeter, 1934). However, previous research largely neglects the effect on the customer's perception of value. Although previous research briefly references this notion (e.g., Michel et al., 2008), most research focuses on aspects connected to the offering's characteristics. Because value creation and customer focus are central, service innovation seems to naturally focus more on the value co-creating experiences of the benefitting party(s). Similarly, the financial value captured by service innovating firms rarely is considered. Service innovations seem to miss the goals due to an inward focus on service characteristic changes for a specific firm. Reinstating the notions that service innovation 
implies "newness" of value co-creation to the market or the world (i.e., customers) and financial value extends from the introduction of a service to success in the market is needed to identify and understand true service innovations.

Schumpeter (1934) focuses on both the outcome and the process of service innovation. He emphasizes that most innovations combine available products and services. On the other hand, Gallouj and Weinstein (1997) identify recombinative innovation as a key innovation mode. Arguably, including both the concept's outcome and process hampers the theoretical development of the service innovation concept. For the customer, how the service’s new characteristics are developed does not matter; the key is the value co-created through the new service. Separating outcome and process aids the theoretical development of both innovating and innovation. The present literature review is a first step towards separating innovating and innovation and overcomes the lack of methodological rigor present in previous literature reviews on service innovation.

For managers, this study provides directions on how to discuss service innovation in the boardroom. Viewing new services from the standpoint of customer value co-creation and financial value allows firms to both better define the innovation and more efficiently capture value. Most research articles emphasize service innovation’s role in developing individual firms and the economy as a whole (Ordanini \& Parasuraman, 2011); however, this study shows disparate views about service innovation's meaning. The literature review shows that a service innovation ranges from offering the world something new to an improvement of a firm’s single service activity. Clearly, service innovations need to be understood from the perspective of how they affect the customer and the firm. 


\section{References}

Alam, I. I. (2012). New service development in India’s business-to-business financial services sector. Journal of Business \& Industrial Marketing, 27(3), 228-241.

Amara, N., Landry, R., \& Doloreux, D. (2009). Patterns of innovation in knowledgeintensive business services. The Service Industries Journal, 29(4), 407-430.

Bröchner, J. (2010). Construction contractors as service innovators. Building Research \& Information, 38(3), 235-246.

Brown, L., \& Osborne, S. P. (2013). Risk and Innovation: Towards a framework for risk governance in public services. Public Management Review, 15(2), 186-208.

Carlborg, P., Kindström, D., \& Kowalkowski, C. (2014). The evolution of service innovation research: a critical review and synthesis. The Service Industries Journal, 34(5), 373-398.

Chan, A., Go, F. M., \& Pine, R. (1998). Service Innovation in Hong Kong: Attitudes and Practice. The Service Industries Journal, 18(2), 112-124.

Chang, Y.-C., Linton, J. D., \& Chen, M.-N. (2012). Service regime: An empirical analysis of innovation patterns in service firms. Technological Forecasting and Social Change, 79(9), 1569-1582.

Cheng, C. C., \& Krumwiede, D. (2011). The effects of market orientation on new service performance: the mediating role of innovation. International Journal of Services Technology and Management, 16(1), 49-73.

Chen, J.-S., Hung Tai Tsou, \& Huang, A. Y.-H. (2009). Service Delivery Innovation: Antecedents and Impact on Firm Performance. Journal of Service Research, 12(1), 36-55. 
Coombs, R., \& Miles, I. (2000). Innovation, Measurement and Services: The New Problematique. In J. S. Metcalfe \& I. Miles (Eds.), Innovation Systems in the Service Economy (pp. 85-103). Springer US.

Corrocher, N., \& Zirulia, L. (2010). Demand and innovation in services: The case of mobile communications. Research Policy, 39(7), 945-955.

De Vries, E. J. (2006). Innovation in services in networks of organizations and in the distribution of services. Research Policy, 35(7), 1037-1051.

Doloreux, D., \& Shearmur, R. (2010). Exploring and comparing innovation patterns across different knowledge intensive business services. Economics of Innovation and New Technology, 19(7), 605-625.

Dotzel, T., Shankar, V., \& Berry, L. L. (2013). Service Innovativeness and Firm Value. Journal of Marketing Research, 50(2), 259-276.

Drejer, I. (2004). Identifying innovation in surveys of services: a Schumpeterian perspective. Research Policy, 33(3), 551-562.

Droege, H., Hildebrand, D., \& Forcada, M. A. H. (2009). Innovation in services: present findings, and future pathways. Journal of Service Management, 20(2), 131-155.

Ferreira, J. J. M., Raposo, M. L., \& Fernandes, C. I. (2013). Does innovativeness of knowledge-intensive business services differ from other industries? The Service Industries Journal, 33(7-8), 734-748.

Fuglsang, L., Sundbo, J., \& Sørensen, F. (2011). Dynamics of experience service innovation: innovation as a guided activity - results from a Danish survey. The Service Industries Journal, 31(5), 661-677.

Gallouj, F., \& Savona, M. (2008). Innovation in services: a review of the debate and a research agenda. Journal of Evolutionary Economics, 19(2), 149-172. 
Gallouj, F., \& Weinstein, O. (1997). Innovation in services. Research Policy, 26(4-5), 537556.

Gebauer, H., Krempl, R., Fleisch, E., \& Friedli, T. (2008). Innovation of product-related services. Managing Service Quality, 18(4), 387-404.

Gotsch, M., \& Hipp, C. (2012). Measurement of innovation activities in the knowledgeintensive services industry: a trademark approach. The Service Industries Journal, 32(13), 2167-2184.

Grolleau, G., Mzoughi, N., \& Pekovic, S. (2013). Is there a relationship between workplace atmosphere and innovation activities? An empirical analysis among French firms. Economics of Innovation and New Technology, 22(6), 566-580.

Grönroos, C. (2011). A service perspective on business relationships: The value creation, interaction and marketing interface. Industrial Marketing Management, 40(2), 240247.

Gustafsson, A., Kristensson, P., \& Witell, L. (2012). Customer co-creation in service innovation: a matter of communication? Journal of Service Management, 23(3), 311327.

Harris, R., McAdam, R., McCausland, I., \& Reid, R. (2013). Levels of innovation within SMEs in peripheral regions: the role of business improvement initiatives. Journal of Small Business and Enterprise Development, 20(1), 102-124.

He, W., \& Abdous, M. (2013). An online knowledge-centred framework for faculty support and service innovation. VINE, 43(1), 96-110.

Hsieh, J.-K., Chiu, H.-C., Wei, C.-P., Yen, H. R., \& Cheng, Y.-C. (2013). A practical perspective on the classification of service innovations. Journal of Services Marketing, 27(5), 371-384. 
Janeiro, P., Proença, I., \& Gonçalves, V. da C. (2013). Open innovation: Factors explaining universities as service firm innovation sources. Journal of Business Research, 66(10), 2017-2023.

Khan, M., \& Khan, M. A. (2009). How technological innovations extend services outreach to customers: The changing shape of hospitality services taxonomy. International Journal of Contemporary Hospitality Management, 21(5), 509-522.

Lovelock, C. H. (1983). Classifying Services to Gain Strategic Marketing Insights. Journal of Marketing, 47(3), 9-20.

Lyons, R., Chatman, J., \& Joyce, C. (2007). Innovation in services: Corporate culture and investment banking. California Management Review, 50(1), 174-191.

MacInnis, D. J. (2011). A Framework for Conceptual Contributions in Marketing. Journal of Marketing, 75(4), 136-154.

Mansury, M. A., \& Love, J. H. (2008). Innovation, productivity and growth in US business services: A firm-level analysis. Technovation, 28(1-2), 52-62.

Martínez-Ros, E., \& Orfila-Sintes, F. (2009). Innovation activity in the hotel industry. Technovation, 29(9), 632-641.

Menor, L. J., \& Roth, A. V. (2007). New service development competence in retail banking: Construct development and measurement validation. Journal of Operations Management, 25(4), 825-846.

Michel, S., Brown, S. W., \& Gallan, A. S. (2008). Service-Logic innovations: How to Innovate Customers, Not Products. California Management Review, 50(3), 49-65.

Möller, K., Rajala, R., \& Westerlund, M. (2008). Service Innovation Myopia? A New Recipe for Client-Provider Value Creation. California Management Review, 50(3), $31-48$. 
Mulgan, G., Tucker, S., Ali, R., \& Sanders, B. (2007). Social innovation: what it is, why it matters and how it can be accelerated. (http://eureka.bodleian.ox.ac.uk/761/)

Oke, A. (2007). Innovation types and innovation management practices in service companies. International Journal of Operations \& Production Management, 27(6), $564-587$.

Ordanini, A., \& Parasuraman, A. (2010). Service Innovation Viewed Through a ServiceDominant Logic Lens: A Conceptual Framework and Empirical Analysis. Journal of Service Research, 14(1), 3-23.

Organisation for Economic Co-operation and Development (OECD). (2005). Oslo manual: Guidelines for collecting and interpreting innovation data. OECD publishing.

Ostrom, A.L., Bitner, M.J., Brown, S.W., Burkhard, K.A., Goul, M., Smith-Daniels, V., Demirkan, H., \& Rabinovich, E. (2010), Moving Forward and Making a Difference: Research Priorities for the Science of Service. Journal of Service Research, 18(2), 127-159.

Ostrom, A. L., Parasuraman, A., Bowen, D. E., Patricio, L., \& Voss, C. A. (2015). Service Research Priorities in a Rapidly Changing Context. Journal of Service Research, 13(1), 4-36.

Paallysaho, S., \& Kuusisto, J. (2008). Intellectual property protection as a key driver of service innovation: an analysis of innovative KIBS businesses in Finland and the UK. International Journal of Services Technology and Management, 9(3), 268-284.

Pearson, R. (1997). Towards an historical model of services innovation: The case of the insurance industry, 1700-1914. The Economic History Review, 50(2), 235-256.

Rosch, E., Mervis, C. B., Gray, W. D., Johnson, D. M., \& Boyes-Braem, P. (1976). Basic objects in natural categories. Cognitive Psychology, 8(3), 382-439. 
Salunke, S., Weerawardena, J., \& McColl-Kennedy, J. R. (2013). Competing through service innovation: The role of bricolage and entrepreneurship in project-oriented firms. Journal of Business Research, 66(8), 1085-1097.

Saviotti, P. P., \& Metcalfe, J. S. (1984). A theoretical approach to the construction of technological output indicators. Research Policy, 13(3), 141-151.

Savona, M., \& Steinmueller, W. E. (2013). Service output, innovation and productivity: A time-based conceptual framework. Structural Change and Economic Dynamics, 27, 118-132.

Schumpeter, J. A. (1934). The theory of economic development: An inquiry into profits, capital, credit, interest, and the business cycle (Vol. 55). Transaction Publishers.

Smith, K. B. (2002). Typologies, Taxonomies, and the Benefits of Policy Classification. Policy Studies Journal, 30(3), 379-395.

Sørensen, F., Sundbo, J., \& Mattsson, J. (2013). Organisational conditions for service encounter-based innovation. Research Policy, 42(8), 1446-1456.

Sundbo, J. (1997). Management of Innovation in Services. The Service Industries Journal, 17(3), 432-455.

Sundbo, J., Johnston, R., Mattsson, J., \& Millett, B. (2001). Innovation in service internationalization: the crucial role of the frantrepreneur. Entrepreneurship \& Regional Development, 13(3), 247-267.

Thakur, R., \& Hale, D. (2013). Service innovation: A comparative study of U.S. and Indian service firms. Journal of Business Research, 66(8), 1108-1123.

Toivonen, M., \& Tuominen, T. (2009). Emergence of innovations in services. The Service Industries Journal, 29(7), 887-902. 
Tranfield, D., Denyer, D., \& Smart, P. (2003). Towards a Methodology for Developing Evidence-Informed Management Knowledge by Means of Systematic Review. British Journal of Management, 14(3), 207-222.

Van der Aa, W., \& Elfring, T. (2002). Realizing innovation in services. Scandinavian Journal of Management, 18(2), 155-171.

Vargo, S. L., \& Lusch, R. F. (2004). Evolving to a New Dominant Logic for Marketing. Journal of Marketing, 68(1), 1-17.

Vargo, S. L., Lusch, R. F., Akaka, M. A., \& He, Y. (2010). Service-dominant logic: a review and assessment. Review of Marketing Research, 6, 125-167.

Vaux Halliday, S., \& Trott, P. (2010). Relational, interactive service innovation: building branding competence. Marketing Theory, 10(2), 144-160.

Windrum, P., \& García-Goñi, M. (2008). A neo-Schumpeterian model of health services innovation. Research Policy, 37(4), 649-672.

Windrum, P., \& Koch, P. M. (Eds.). (2008). Innovation in public sector services: entrepreneurship, creativity and management. Edward Elgar Publishing.

Witell, L., Anderson, L., Brodie, R., Colurcio, M., Edvardsson, B., Kristensson, P., Olsen, L., Sebastiani, R., \& Wallin-Andreassen, T. (2015). Exploring dualities of service innovation: Implications for service research, Journal of Service Marketing, 29, 436441.

Yoon, B., Kim, S., \& Rhee, J. (2012). An evaluation method for designing a new productservice system. Expert Systems with Applications, 39(3), 3100-3108.

Zirger, B. J., \& Maidique, M. A. (1990). A Model of New Product Development: An Empirical Test. Management Science, 36(7), 867-883.

Zolfagharian, M., \& Paswan, A. (2008). Do consumers discern innovations in service elements? Journal of Services Marketing, 22(5), 338-352. 
Table 1

Studies viewing service innovation as a degree of change in the offering

\begin{tabular}{|c|c|c|c|c|}
\hline Author & Context & Concept & Type of study & Content of categories \\
\hline $\begin{array}{l}\text { Gallouj and } \\
\text { Weinstein (1997) }\end{array}$ & & Innovation & Conceptual & $\begin{array}{l}\text { Radical, improvement, } \\
\text { incremental, ad hoc, } \\
\text { recombinative, formalization }\end{array}$ \\
\hline Sundbo (1997) & Service firms & $\begin{array}{l}\text { Innovation in } \\
\text { services }\end{array}$ & Conceptual & $\begin{array}{l}\text { Radical innovations, large } \\
\text { incremental, small } \\
\text { incremental, general acts of } \\
\text { learning, individual acts of } \\
\text { learning }\end{array}$ \\
\hline Chan et al. (1998) & Services & Innovation & $\begin{array}{l}\text { Empirical, survey } \\
(\mathrm{n}=99)\end{array}$ & $\begin{array}{l}\text { Incremental, distinctive (old- } \\
\text { new), distinctive (new-old), } \\
\text { breakthrough }\end{array}$ \\
\hline de Vries (2006) & & Innovation & $\begin{array}{l}\text { Empirical, case } \\
\text { study }\end{array}$ & $\begin{array}{l}\text { Radical, improvement, } \\
\text { incremental, ad hoc, } \\
\text { recombinative, formalization }\end{array}$ \\
\hline Lyons et al. (2007) & $\begin{array}{l}\text { Investment } \\
\text { banking }\end{array}$ & $\begin{array}{l}\text { Service } \\
\text { innovation }\end{array}$ & Conceptual & Radical, incremental \\
\hline Oke (2007) & Services & $\begin{array}{l}\text { Service } \\
\text { innovation }\end{array}$ & $\begin{array}{l}\text { Empirical, } \\
\text { interviews }(\mathrm{n}=6) \text {, } \\
\text { survey }(\mathrm{n}=101)\end{array}$ & $\begin{array}{l}\text { Radical, “me-too," } \\
\text { incremental }\end{array}$ \\
\hline Möller et al. (2008) & & $\begin{array}{l}\text { Service } \\
\text { innovation }\end{array}$ & $\begin{array}{l}\text { Conceptual with } \\
\text { empirical } \\
\text { illustrations }\end{array}$ & $\begin{array}{l}\text { Established services, } \\
\text { incremental, radical }\end{array}$ \\
\hline $\begin{array}{l}\text { Windrum and } \\
\text { García-Goñi } \\
\text { (2008) }\end{array}$ & Healthcare & $\begin{array}{l}\text { Health services } \\
\text { innovation }\end{array}$ & $\begin{array}{l}\text { Empirical, case } \\
\text { study }\end{array}$ & Radical, incremental \\
\hline $\begin{array}{l}\text { Martínez-Ros and } \\
\text { Orfila-Sintes } \\
\text { (2009) }\end{array}$ & Hotel services & Innovation & $\begin{array}{l}\text { Empirical, } \\
\text { interview survey } \\
(\mathrm{n}=331)\end{array}$ & Radical, incremental \\
\hline $\begin{array}{l}\text { Cheng and } \\
\text { Krumwiede (2010) }\end{array}$ & Service firms & $\begin{array}{l}\text { Service } \\
\text { innovation }\end{array}$ & $\begin{array}{l}\text { Empirical, survey } \\
(\mathrm{n}=253)\end{array}$ & Radical, incremental \\
\hline $\begin{array}{l}\text { Corrocher and } \\
\text { Zirulia }\end{array}$ & $\begin{array}{l}\text { Mobile } \\
\text { operators }\end{array}$ & Innovation & $\begin{array}{l}\text { Empirical, } \\
\text { analysis of } \\
\text { documents }\end{array}$ & $\begin{array}{l}\text { Incremental, recombinative, } \\
\text { improvement }\end{array}$ \\
\hline $\begin{array}{l}\text { Gustafsson et al. } \\
\text { (2012) }\end{array}$ & Services & $\begin{array}{l}\text { Service } \\
\text { innovation }\end{array}$ & $\begin{array}{l}\text { Empirical, survey } \\
(\mathrm{n}=284)\end{array}$ & $\begin{array}{l}\text { Radical, improvement, } \\
\text { incremental }\end{array}$ \\
\hline $\begin{array}{l}\text { Brown and } \\
\text { Osborne (2013) }\end{array}$ & $\begin{array}{l}\text { Public } \\
\text { services }\end{array}$ & Innovation & Conceptual & Transformational, incremental \\
\hline Harris et al. (2013) & SME & Innovation & $\begin{array}{l}\text { Empirical, survey } \\
(\mathrm{n}=606)\end{array}$ & $\begin{array}{l}\text { Radical, incremental, } \\
\text { noninnovative }\end{array}$ \\
\hline $\begin{array}{l}\text { Janeirio et al. } \\
\text { (2013) }\end{array}$ & Service firms & $\begin{array}{l}\text { Service } \\
\text { innovation }\end{array}$ & $\begin{array}{l}\text { Empirical, survey } \\
(\mathrm{n}=967)\end{array}$ & Radical, incremental \\
\hline $\begin{array}{l}\text { Savona and } \\
\text { Steinmueller } \\
\text { (2013) }\end{array}$ & & Innovation & Conceptual & Radical, incremental \\
\hline $\begin{array}{l}\text { Sundbo et al. } \\
\text { (2001) }\end{array}$ & Franchisors & $\begin{array}{l}\text { Service } \\
\text { innovation }\end{array}$ & $\begin{array}{l}\text { Empirical, case } \\
\text { study }\end{array}$ & $\begin{array}{l}\text { Service product, architectural, } \\
\text { modification, ad hoc }\end{array}$ \\
\hline
\end{tabular}


Table 2

Studies viewing service innovation product/process

\begin{tabular}{|c|c|c|c|c|}
\hline Author & Context & Term & Type of study & Content of categories \\
\hline Pearson (1997) & $\begin{array}{l}\text { Insurance } \\
\text { industry }\end{array}$ & Innovation & Conceptual & $\begin{array}{l}\text { Process, primary product, } \\
\text { secondary process }\end{array}$ \\
\hline Amara et al. (2009) & KIBS & Service innovation & $\begin{array}{l}\text { Empirical, } \\
\text { survey } \\
(\mathrm{n}=1142)\end{array}$ & $\begin{array}{l}\text { Product, process, delivery, } \\
\text { strategic, managerial, } \\
\text { marketing }\end{array}$ \\
\hline $\begin{array}{l}\text { Khan and Khan } \\
\text { (2009) }\end{array}$ & $\begin{array}{l}\text { Hospitality } \\
\text { Services }\end{array}$ & $\begin{array}{l}\text { Services } \\
\text { innovation }\end{array}$ & Conceptual & $\begin{array}{l}\text { Major service innovations, } \\
\text { service-line extension, service } \\
\text { and style improvements, } \\
\text { major process innovation, } \\
\text { process-line extensions, } \\
\text { process improvements }\end{array}$ \\
\hline $\begin{array}{l}\text { Doloreux and } \\
\text { Shearmur (2010) }\end{array}$ & KIBS & Service innovation & $\begin{array}{l}\text { Empirical, } \\
\text { survey } \\
(\mathrm{n}=769)\end{array}$ & $\begin{array}{l}\text { Product, process, delivery, } \\
\text { strategic, managerial, } \\
\text { marketing }\end{array}$ \\
\hline $\begin{array}{l}\text { Sørensen et al. } \\
\text { (2010) }\end{array}$ & & Innovation & Conceptual & $\begin{array}{l}\text { Products or services, } \\
\text { production processes, } \\
\text { marketing procedures, } \\
\text { organizational setups }\end{array}$ \\
\hline $\begin{array}{l}\text { Vaux Halliday and } \\
\text { Trott (2010) }\end{array}$ & & Service innovation & Conceptual & $\begin{array}{l}\text { Service product, service } \\
\text { process }\end{array}$ \\
\hline $\begin{array}{l}\text { Fuglsang et al. } \\
\text { (2011) }\end{array}$ & Services & $\begin{array}{l}\text { Experience } \\
\text { service innovation }\end{array}$ & $\begin{array}{l}\text { Empirical, } \\
\text { survey } \\
(\mathrm{n}=1315)\end{array}$ & Product, process \\
\hline Chang et al. (2012) & Service firms & Service innovation & $\begin{array}{l}\text { Empirical, } \\
\text { survey } \\
(\mathrm{n}=5711)\end{array}$ & $\begin{array}{l}\text { Product, process, organization, } \\
\text { business model }\end{array}$ \\
\hline $\begin{array}{l}\text { Gotsch and Hipp } \\
\text { (2012) }\end{array}$ & KIBS & Service innovation & $\begin{array}{l}\text { Empirical, } \\
\text { survey } \\
(\mathrm{n}=278)\end{array}$ & $\begin{array}{l}\text { Product, process, marketing, } \\
\text { organizational innovation }\end{array}$ \\
\hline Ferreira et al. (2013) & KIBS & Innovation & $\begin{array}{l}\text { Empirical, } \\
\text { survey }(n=69)\end{array}$ & $\begin{array}{l}\text { Products/services, processes, } \\
\text { organizational }\end{array}$ \\
\hline $\begin{array}{l}\text { Grolleau et al. } \\
\text { (2013) }\end{array}$ & French firms & Innovation & $\begin{array}{l}\text { Empirical, } \\
\text { Survey } \\
(\mathrm{n}=5574)\end{array}$ & $\begin{array}{l}\text { Product/services, process, } \\
\text { organization, marketing }\end{array}$ \\
\hline $\begin{array}{l}\text { Salunke et al. } \\
\text { (2013) }\end{array}$ & Service firms & $\begin{array}{l}\text { Service } \\
\text { Innovation }\end{array}$ & $\begin{array}{l}\text { Empirical, } \\
\text { interviews } \\
(\mathrm{n}=14), \\
\text { survey } \\
(\mathrm{n}=192)\end{array}$ & Interactive, supportive \\
\hline
\end{tabular}


Table 3

Studies viewing service innovation as newness

\begin{tabular}{lllll}
\hline Author & Context & Term & Type of study & Content of categories \\
\hline $\begin{array}{l}\text { Mansury and } \\
\text { Love (2008) }\end{array}$ & $\begin{array}{l}\text { US } \\
\text { Business } \\
\text { firms }\end{array}$ & Innovation & $\begin{array}{l}\text { Empirical, } \\
\text { survey (n=206) }\end{array}$ & $\begin{array}{l}\text { New-to-market innovation, new-to-firm } \\
\text { innovation }\end{array}$ \\
$\begin{array}{l}\text { Chen et al. } \\
(2009)\end{array}$ & $\begin{array}{l}\text { Financial } \\
\text { firms }\end{array}$ & $\begin{array}{l}\text { Service } \\
\text { delivery } \\
\text { innovation }\end{array}$ & $\begin{array}{l}\text { Empirical, } \\
\text { survey (n=298) }\end{array}$ & $\begin{array}{l}\text { New service channels for existing customer } \\
\text { service, new service channels for new customer } \\
\text { service }\end{array}$ \\
Alam (2012) & $\begin{array}{l}\text { Service } \\
\text { firms }\end{array}$ & $\begin{array}{l}\text { Service } \\
\text { innovation }\end{array}$ & $\begin{array}{l}\text { Empirical, } \\
\text { survey (n=274) }\end{array}$ & $\begin{array}{l}\text { New-to-the market services, new-to-the firm } \\
\text { services, new delivery processes, service } \\
\text { modification, service line extension, service } \\
\text { repositioning }\end{array}$ \\
& $\begin{array}{l}\text { Service } \\
\text { industries }\end{array}$ & $\begin{array}{l}\text { Service } \\
\text { innovation }\end{array}$ & $\begin{array}{l}\text { Empirical, } \\
\text { survey (n=315) }\end{array}$ & $\begin{array}{l}\text { New-to-market innovation, new-to-firm } \\
\text { innovation }\end{array}$ \\
\hline
\end{tabular}


Table 4

Studies viewing service innovation as a change in the means of provision

\begin{tabular}{|c|c|c|c|c|}
\hline Author & Context & Term & Type of study & Content of categories \\
\hline $\begin{array}{l}\text { van der Aa } \\
\text { and } \\
\text { Elfring } \\
(2002)\end{array}$ & $\begin{array}{l}\text { Service } \\
\text { industries }\end{array}$ & Innovation & $\begin{array}{l}\text { Empirical, case study } \\
(\mathrm{n}=9)\end{array}$ & Technological, organizational \\
\hline $\begin{array}{l}\text { Dotzel et } \\
\text { al. (2013) }\end{array}$ & Us firms & $\begin{array}{l}\text { Service } \\
\text { innovation }\end{array}$ & $\begin{array}{l}\text { Empirical, panel data } \\
\text { of service innovations }\end{array}$ & $\begin{array}{l}\text { Internet enabled innovation (e-innovation), } \\
\text { people enabled innovation (p-innovation) }\end{array}$ \\
\hline $\begin{array}{l}\text { Yoon et al. } \\
(2012)\end{array}$ & $\begin{array}{l}\text { Car- } \\
\text { sharing } \\
\text { service }\end{array}$ & $\begin{array}{l}\text { Service } \\
\text { innovation }\end{array}$ & $\begin{array}{l}\text { Empirical, survey } \\
\text { individuals }(n=113) \text {, } \\
\text { organizations }(n=14) \text {, } \\
\text { Simulation }\end{array}$ & $\begin{array}{l}\text { New or improved service products, new or } \\
\text { improved ways of designing and producing } \\
\text { services in the service process, } \\
\text { organizational innovation, the management } \\
\text { of the innovation process in service } \\
\text { organizations }\end{array}$ \\
\hline $\begin{array}{l}\text { He and } \\
\text { Abdous } \\
(2013)\end{array}$ & $\begin{array}{l}\text { Higher } \\
\text { education }\end{array}$ & $\begin{array}{l}\text { Service } \\
\text { innovation }\end{array}$ & Conceptual & Service, technological, administrative \\
\hline
\end{tabular}


Table 5 Overview of the categorizations of service innovation.

\begin{tabular}{|c|c|c|c|c|}
\hline & Degree of change & Type of change & Newness & Means of provision \\
\hline $\begin{array}{l}\text { Main } \\
\text { categories }\end{array}$ & $\begin{array}{l}\text { Radical, } \\
\text { incremental }\end{array}$ & Product, process & $\begin{array}{l}\text { New to the } \\
\text { market, new to } \\
\text { the firm }\end{array}$ & Technology, organization \\
\hline Explanation & $\begin{array}{l}\text { A service } \\
\text { innovation is based } \\
\text { on new core } \\
\text { characteristics or } \\
\text { improvements to } \\
\text { existing core } \\
\text { characteristics. }\end{array}$ & $\begin{array}{l}\text { A service } \\
\text { innovation is } \\
\text { based on changes } \\
\text { in the core } \\
\text { characteristics } \\
\text { related to the } \\
\text { output or service } \\
\text { provision. }\end{array}$ & $\begin{array}{l}\text { A service } \\
\text { innovation that } \\
\text { has not been } \\
\text { provided by } \\
\text { competitors or is } \\
\text { a new service } \\
\text { for the specific } \\
\text { service provider. }\end{array}$ & $\begin{array}{l}\text { A service innovation is } \\
\text { provided in a new way } \\
\text { through technology or new } \\
\text { organizational arrangements. }\end{array}$ \\
\hline $\begin{array}{l}\text { Core } \\
\text { references }\end{array}$ & $\begin{array}{l}\text { Gallouj and } \\
\text { Weinstein (1997) }\end{array}$ & Pearson (1997) & $\begin{array}{l}\text { Mansury and } \\
\text { Love (2008) }\end{array}$ & $\begin{array}{l}\text { van der Aa and Elfring } \\
\text { (2002) }\end{array}$ \\
\hline
\end{tabular}

